\title{
WŁASNOŚĆ INTELEKTUALNA JAKO KLUCZOWY ZASÓB ORGANIZACJI INNOWACYJNEJ
}

DOI: $10.33141 /$ po.2020.05.02

\section{Aldona Małgorzata Dereń}

\section{Wprowadzenie}

W łasność intelektualna staje się kluczowym czynnikiem sukcesu innowacyjnych organizacji, co podkreśla się w pracach teoretyków i praktyków zarządzania (Drucker, 1992; Bratnicki, Strużyna, 2001; Grandstrand, 1999). Główne kategorie własności intelektualnej to prawo autorskie oraz prawo własności przemysłowej. Obecnie często mówi się również o trzecim elemencie - tzn. know-how.

Własność intelektualna jest pojęciem rozwijającym się i dotyczy generalnie wyników ludzkiej kreatywności i inwencji. Można do niej zaliczyć wszystko to, co powstało $\mathrm{w}$ drodze procesu myślowego, intelektualnego i zostało ujęte $\mathrm{w}$ postaci materialnej. Własność intelektualna to zasoby organizacji, które mają charakter niematerialny. W znacznym stopniu mają one charakter bezwzględny i wyłączny - przyznają właścicielowi monopol na pewne dobra; zazwyczaj mają charakter majątkowy. Cechą,
Przegląd Organizacji, Nr 5(964), 2020, s. 10-19

www.przegladorganizacji.pl

๑) Towarzystwo Naukowe Organizacji i Kierownictwa (TNOiK) którą czujemy intuicyjnie, jest zdolność do korzystania $\mathrm{z}$ nich bez możliwości ich wyczerpania $\mathrm{w}$ wielu miejscach, w przeciwieństwie do zasobów materialnych, które są wykorzystywane w konkretnym miejscu ich lokalizacji. Duże organizacje skuteczniej gospodarują własnością intelektualną. Natomiast mikro-, małe i średnie organizacje mają $\mathrm{w}$ tym zakresie ograniczone możliwości poznawcze i praktyczne. Charakterystycznymi cechami zasobów własności intelektualnej są niezawłaszczalność, niepoliczalność, niepodzielność, zdolność do komercjalizacji, użyteczność, zdolność do zabezpieczania (ochrony) i strategiczność. Tematyka własności intelektualnej jako kluczowego zasobu strategicznego organizacji w Polsce wymaga pogłębionej analizy badawczej.

Celem niniejszego opracowania jest wskazanie i analiza specyficznych cech własności intelektualnej, które determinują ich ukierunkowanie jako kluczowego zasobu 
strategicznego organizacji w kontekście rozwoju i konkurencyjności przedsiębiorstw w Polsce. Efektywne wykorzystanie cech zasobów intelektualnych w procesie tworzenia innowacji buduje zdolność przedsiębiorstwa do osiągania większej wartości od konkurencyjnych podmiotów.

Podstawą prezentowanej w pracy analizy jest Raport Urzędu Unii Europejskiej do Spraw Własności Intelektualnej (ang. European Union Intelectual Property Office - EUIPO), w którym opublikowano zestawienie wyników dla MŚP w zakresie własności intelektualnej przedsiębiorstw europejskich. Raport ten oraz badania własne przeprowadzone pod koniec 2015 roku w grupie 137 przedsiębiorstw z województwa dolnośląskiego (Dereń, 2015), a także ponowne badania przeprowadzone na przełomie lat 2018/2019 na mniejszej grupie respondentów obrazują kluczowe problemy w zakresie podejścia i postrzegania własności intelektualnej w tej grupie przedsiębiorstw. Wiedza i świadomość co do istoty własności intelektualnej w mikro, małych i średnich przedsiębiorstwach jest na tak niskim poziomie, że ogranicza to perspektywę rozwojową większości tych przedsiębiorstw jako organizacji innowacyjnych. Tej słabości może zapobiec poznanie specyfiki własności intelektualnej jako strategicznego zasobu zorientowanego prorozwojowo i jednego $\mathrm{z}$ filarów funkcjonowania współczesnego przedsiębiorstwa.

\section{Pojęcie własności intelektualnej}

W edług definicji sformułowanej przez Światową Organizację Własności Intelektualnej (ang. World Intellectual Property Organization - WIPO), własność intelektualna oznacza różnorodne wytwory umysłu człowieka, takie jak wynalazki, utwory literackie i artystyczne oraz symbole, nazwy, grafiki i wzory stosowane w szeroko rozumianej gospodarce. Obejmuje ona zarówno wytwory i oznaczenia mające zastosowanie dla celów działalności gospodarczej (własność przemysłowa), jak i dzieła będące przedmiotem twórczości autorskiej, tj. utwory o charakterze naukowym, literackim i artystycznym (Konwencja WIPO, 1967).

Własność intelektualna jest ściśle związana $\mathrm{z}$ procesami tworzenia, rozwijania i wykorzystywania zdobytej wiedzy, posiadanych doświadczeń i kompetencji oraz stanowi wynik ludzkiej twórczości, kreatywności, zachowań przedsiębiorczych, pomysłów i inwencji. Własność intelektualną wyróżnia to, że można określić jej wartość ekonomiczną i podlega ona ochronie prawnej (Blair, Cotter, 2005, s. 1-2). Ochrona ta już na poziomie twórczych rezultatów jest ważną umiejętnością strategiczną w rozwoju przedsiębiorstw, bowiem dzięki niej organizacje mogą być partnerami w rywalizacji rynkowej, a nawet zwycięzcami i liderami. Znaczenie tej umiejętności coraz bardziej rośnie we współczesnej gospodarce, w której zasoby intelektualne wymagają nie tylko nakładów finansowych, ale również działań związanych z ich zabezpieczeniem.

W praktyce warunkiem nadal w niedostatecznym stopniu docenianym, a determinującym cały proces kreowania i ochrony innowacyjnej aktywności pracowników jest wypracowanie myślenia w kategoriach strategii. Może to być utożsamiane ze strategią innowacyjną lub innowacyjności, która jest pochodną przyjętego modelu biznesu i powinna być spójna ze strategią ogólną przedsiębiorstwa (Pisano, 2015, s. 95). Ponoszone koszty i straty wynikające $z$ braku wiedzy (i przekonania) o istocie własności intelektualnej mogą być dotkliwe. Mimo ciągle rosnących wskaźników publikowanych przez World Intellectual Property Organization (WIPO) czy European Patent Office (EPO), świadczących o coraz większej świadomości w tym zakresie, praktyka gospodarcza pokazuje wiele przykładów przedsiębiorstw europejskich, które nie mają odpowiedniej wiedzy lub świadomości dotyczących możliwości zabezpieczania (ochrony) własności intelektualnej (Bainbridge, 2009, s. 22-30). Problem ten dotyczy również polskiej gospodarki. Jak twierdzi L. Palmen (2017), priorytetem dla naszych przedsiębiorstw powinno być podniesienie ich wartości i produktywności poprzez rozwój rynku nowoczesnych rozwiązań, przedsiębiorstw typu startup, tworzenie innowacyjnych firm-czempionów. Realizacja tych postulatów wiąże się z koniecznością tworzenia społeczeństwa otwartego na testowanie innowacji. W takim społeczeństwie menedżerowie muszą mieć wiedzę o własności intelektualnej i jej roli w kreowaniu wartości przedsiębiorstwa.

\section{Cechy własności intelektualnej jako zasobu organizacji innowacyjnej}

W dyskursie na temat własności intelektualnej zarówno ekonomiści, socjologowie, prawnicy, jak i specjaliści od zachowań organizacyjnych akcentują społeczną naturę własności intelektualnej. Takie określenie wyraźnie podkreśla kontekst zasobowy własności intelektualnej. Określając stosunek jednostek i zbiorowości jako szczególne dobro - produkt pracy umysłowej - nawiązywany w zamiarze jego wykorzystania, podkreśla się jego walory użyteczności.

Postrzeganie własności intelektualnej jako zasobu o określonych cechach (atrybutach) pozwala na ukazanie jej specyfiki, często tak trudnej do zrozumienia z punktu widzenia tradycji, wspieranej ustalonymi zasadami i normami traktowania zasobów materialnych jako fundamentalnej podstawy gospodarowania.

W dyskursie publicznym czy praktycznym pojęcie własności intelektualnej jest na ogół często utożsamiane $\mathrm{z}$ własnością pojmowaną $\mathrm{w}$ kategoriach prawnych. Takie podejście uznać należy za niewłaściwie zawężone z uwagi na posiadane cechy (właściwości) własności intelektualnej, a przede wszystkim $\mathrm{z}$ uwagi na fakt, że jest ona ściśle powiązana z człowiekiem. Właściwości te pozwalają na zróżnicowanie i specyfikę kształtowania się własności intelektualnej jako zasobu.

Pierwsza $z$ nich to niezawłaszczalność. Idea czy nowe rozwiązanie będące rezultatem twórczej aktywności człowieka nabywają wartość od momentu ich uzewnętrznienia. Tak więc twórca nie zawłaszcza wytworów własnej twórczości, tak jak właściciel gruntu, który np. zakazuje dostępu do niego. Twórca dysponuje prawem do kontroli sposobu korzystania ze swojego uzewnętrznionego efektu twórczego. W szczególności zainteresowany jest tym, 
aby uniemożliwić rozporządzanie tym efektem w sposób niekontrolowany, np. sprzedażą czy i/lub czerpaniem zeń zysków. Twórca nie może jednak uczynić nic, by zapobiec imitacji swojego pomysłu. Nabywając produkt - rezultat twórczej pracy - zdobywa się szczegółową, odtwórczą wiedzę o tym produkcie, o jego budowie i funkcjach. Prowadzi to do powstawania praktyki naśladownictwa. Badania wskazują, że tego rodzaju odtwórczość jest dominującą sytuacją i nierzadko prowadzi do tzw. innowacji udoskonalających (Clayton i in., 2016, s. 44-53).

W praktyce nowy pomysł, nowa informacja czy nowe rozwiązanie może stanowić początek procesu innowacyjnego, rodząc szereg kolejnych innowacji, które tym trudniej zawłaszczyć czy kontrolować.

Drugą cechą pozwalającą na akcentowanie odmienności własności idei, pomysłów, czy rozwiązań jest ich niepoliczalność. W praktyce bowiem mamy do czynienia ze „światem idei i pomysłów”, a ta niepoliczalność ukazuje bezgraniczne możliwości twórcze ludzi i organizacji.

Trzecią cechą kształtującą specyfikę zasobów intelektualnych jest niepodzielność. Trudno wyobrazić sobie np. zbywalność jedynie części pomysłu albo tylko prawa do jego korzystania. Na tym opiera się zatem ekonomiczny problem oceny opłacalności inwestycji w innowacje (Wiśniewska, 2013, s. 10). Ta naturalna spójność wpływa na podejmowanie decyzji w każdej sytuacji wyborów ekonomicznych. Własność intelektualną charakteryzuje brak możliwości zużycia w trakcie wykorzystania i doskonała płynność, co oznacza, że można ją przekształcić w dowolny zasób materialny (Koźmiński, Jemielniak, 2008, s. 110).

$\mathrm{Z}$ powyższego wynika, że za powstawanie innowacji jako efektu procesu twórczego odpowiadają czynniki nieekonomiczne (ambicja, system wartości, zaangażowanie przedsiębiorcy), które sprzyjają ich rozwojowi, jak również czynniki hamujące dyfuzję informacji: czas, zaawansowanie naukowo-technologiczne nowych pomysłów czy wrodzony konserwatyzm konsumentów i producentów.

Wymieniając właściwości zasobów intelektualnych, należy koniecznie wskazać na zdolność do komercjalizacji. Jest to cecha doprowadzenia własności intelektualnej do postaci pozwalającej na sprzedaż rynkową i konkurowanie. Zdolność ta jest dynamiczna, zmienna i zależna od wielu czynników. Jest ona ukierunkowana na wchłanianie intelektualnej wiedzy i twórczych umiejętności w procesie wytwarzania produkcyjnego, w celu udanego ich urynkowienia w postaci produktu/produktów. Y.S. Rajan (2002, s. 130-139) określa komercjalizację jako „kształtowanie wartości dodanej dla idei, wyników badań, technologii i nowego produktu".

W świetle tej właściwości, jaką jest komercjalizacja, warto przypomnieć, że prywatna własność dóbr materialnych prowadzi z reguły do konkurencji i wręcz jej sprzyja. Natomiast własność intelektualna przeciwnie - prowadzi do powstawania trwałych monopoli, ograniczając konkurencję i współpracę. Ta ostatnia konkluzja oznacza konieczność identyfikowania źródeł (sposobów) pokonywania tych zagrożeń. Problem ten analizował w swoich rozważaniach J. Schumpeter, który opowiadał się za tzw. twórczą destrukcją. Według tego postulatu, na określonym etapie rozwoju technologicznego, monopol intelektualny danego producenta pozwala mu dominować na rynku, ale trwa to krótko, gdyż wskutek konkurencji pojawiają się całkowicie nowe i lepsze pomysły, przekształcane w rozwiązania rodzące nowe produkty. W ten sposób wypierani są ustanowieni wcześniej monopoliści i ustanawiani nowi (Zorska, 2011, s. 21). Teoria ta w istocie zakłada, że monopol sprzyja innowacjom o tyle, o ile występuje konkurencja między innowatorami. W praktyce tak zawiązane monopole są bardzo trwałe. Badania D. Aakera (1991) dowodzą, że w ciągu kilkudziesięciu lat trwałość postrzegania najpopularniejszych marek $\mathrm{w}$ zasadzie pozostaje niezmienna. Jak piszą obrońcy wolności intelektualnej M. Boldren i D. Levine (2008, s. 580): „możemy jedynie zawdzięczać szczęściu lub ówczesnemu sądownictwu, że Apple i IBM nie mogły w latach 70-tych opatentować komputera osobistego i jego głównych komponentów".

Kolejny przymiot własności intelektualnej jako zasobu to użyteczność. Jak piszą R. Krupski i K. Piórkowska (2013, s. 101), badania użyteczności zasobów, które ze swej istoty cechuje niematerialność są trudno mierzalne (albo w ogóle są niemierzalne). „Jak bowiem identyfikować użyteczność tego, co jest ze swej istoty trudne do określenia? Ostatecznie przyjęto, że rozwiązaniem jest określenie ogólnobehawioralnych obszarów aktywności przedsiębiorstwa, również trudnych do pomiaru, a identyfikowanie użyteczności zasobów niematerialnych odbędzie się właśnie w kontekście ich rozwoju. Inaczej: użyteczność zasobów niematerialnych zostanie określona (...) za pomocą kierunków ich wykorzystania, nazwanych tu ogólnobehawioralnymi obszarami aktywności przedsiębiorstwa" (Krupski, Piórkowska, 2013, s. 97). I dalej autorzy piszą: „Identyfikacja użyteczności zasobów niematerialnych zawsze będzie obarczona znaczną subiektywnością, a tym samym będzie kategorią dyskusyjną, przede wszystkim w zakresie ważności i intensywności wpływu (w tym wypadku w obszarach innowacji i replikacji). Jednakże tego typu próby mają znaczenie dla określenia wirtualnych ( $w$ znaczeniu: rozmytych) podstaw przewag konkurencyjnych przedsiębiorstw, trudnych do skopiowania, a więc trwałych, oraz podstaw do wyróżnienia się od tła konkurencyjnego".

Mechanizm społeczny w obrocie własnością intelektualną jest inny niż w przypadku klasycznej własności materialnej. W tej ostatniej nie ma miejsca na „niewłaścicieli” po to, by właściciel miał swobodę sprawowania władztwa nad swoją rzeczą. Tymczasem własność intelektualna, traktując ją jako zasób, owego wykluczenia nie wymaga. Jeśli ktoś jest użytkownikiem rozwiązań będących w domenie publicznej, w niczym nie ogranicza to możliwości użytkowania przez innych. Tak więc zachowuje się społeczną użyteczność tych zasobów. Mało tego, im więcej osób z nich korzysta, tym większa jest umownie korzyść ogólna. Z drugiej strony dobrem, które ulega zmniejszeniu, są dochody, jakie monopol może przynieść właścicielowi wówczas, gdy polega on na wyłączności praw do sprzedaży i udostępniania dóbr. Jest to monopol rozporządzania dobrem. Należy jednak 
podkreślić, że zamykanie dostępu ogranicza możliwość opracowania nowych modeli biznesu opartych na szerokim dostępie użytkowników do własności intelektualnej.

Cechą własności intelektualnej jest również strategiczność. W ujęciu najbardziej ogólnym strategiczność zasobu ma zapewnić przetrwanie i rozwój przedsiębiorstwa, czego wyrazem powinna być zmiana pozycji strategicznej w sektorze. Strategia oparta na zasobach powinna zatem uwzględniać wszystkie zasoby niematerialne organizacji sprzyjające osiągnięciu celów strategicznych. Współcześnie w zbiorze zasobów niematerialnych decydujących o sukcesie przedsiębiorstwa kluczową rolę odgrywa własność intelektualna i zdolność organizacji do ich pomnożenia oraz ochrony.

Strategiczność własności intelektualnej może być różna w zależności od wielkości organizacji. Duże przedsiębiorstwa, które mają znaczne środki finansowe, często szukają strategii opartej na zdobywaniu i utrzymywaniu dużej liczby patentów (portfolio patentów). Natomiast dla większości nowo powstałych przedsiębiorstw czy przedsiębiorstw sektora MŚP rozwój oraz budowanie obszernego zasobu patentowego może być niewspółmiernie kosztowne.

Strategiczność własności intelektualnej przejawia się nie tylko w możliwości sprzedaży własności intelektualnej, ale także w eksploatacji tych zasobów na drodze licencyjnej czy wykorzystaniu ich do wspólnego przedsięwzięcia realizowanego $\mathrm{z}$ innym podmiotem (np. konsorcjum), wykorzystaniu tych zasobów do pozyskania innych praw (tzw. licencja krzyżowa) bądź zastosowaniu do zwiększenia cen produktów lub usług, a także do utworzenia nowej organizacji w oparciu o wyłączne prawa majątkowe.

Nie ma modelowej czy uniwersalnej koncepcji strategii organizacji opartej na własności intelektualnej, odpowiedniej do każdego rodzaju warunków i przedmiotu działalności (Battilan, Cascianno, 2015). Każda organizacja bowiem ma różne cele i dlatego też strategie muszą być tak sformułowane, by umożliwić osiągnięcie określonych celów konkretnej organizacji. Znaczenie własności intelektualnej dla rozwoju przedsiębiorstwa i zwiększenia jego przewagi konkurencyjnej zależy od sektora działalności, strategii gospodarczej oraz wzajemnych relacji ze strategią jego konkurencji. Na przykład, patenty są niezbędne, zwłaszcza w dziedzinach, w których innowacje są proste do skopiowania. Natomiast w innych przypadkach właściwszą metodą może być know-how i zachowanie tajemnicy.

Katalog zasobowych cech własności intelektualnej należy w świetle prowadzonej analizy uzupełnić o zdolność do zabezpieczania (ochrony) (Dereń, 2015, s. 1-40). W obszarze tej właściwości można wyróżnić trzy aspekty zabezpieczania własności intelektualnej jako zasobu. Pierwszy aspekt to określone przez państwo ramy prawne rynkowych procesów wymiany dóbr i usług dla obszaru własności intelektualnej, które ustanawiają porządek prawny określany jako prawo własności intelektualnej. Jest to zbiór legislacyjnych form własności intelektualnej wraz z ich szczególnymi formami jurysdykcyjnymi, ukształtowanymi przez orzecznictwo i rozwój prawa.
Istotnymi elementami tych regulacji prawnych są: prawo patentowe, prawo do wzorów przemysłowych, prawo do wzorów użytkowych, prawo o znakach towarowych oraz prawo autorskie. Regulacje te, opierając się na podstawie konstytucyjnej, tworzą określoną całość, dającą zasadniczą gwarancję własności prywatnej, będącej ogólną i nadrzędną podstawą ochrony prywatnych form własności - koncepcję własności intelektualnej. Do tego aspektu dochodzą również regulacje prawne dotyczące konkurencji, np. ustawa o zwalczaniu nieuczciwej konkurencji lub prawo antymonopolowe. Tworzone przez nie ramy prawne i mechanizmy sprawowania kontroli nakierowane są również na negatywne dla konkurencji skutki oddziaływania form użytkowania własności intelektualnej.

Drugi aspekt ochrony własności intelektualnej dotyczy zabezpieczeń na poziomie organizacji. W grę wchodzi tu wybór instytucjonalnych form, takich jak: patent, prawo ochronne na wzór przemysłowy, prawo ochronne na wzór użytkowy, prawo z rejestracji topografii układu scalonego itp. Pozwalają one uprawnionemu zachować wyłączność korzystania z konkretnego rozwiązania przede wszystkim wtedy, kiedy jest ono ujawnione i rozpowszechnione. Obok tych form możliwa jest również ochrona w postaci tajemnicy przedsiębiorstwa. Pozwala ona na zachowanie w poufności nieujawnionych do wiadomości publicznej informacji, którym można przypisać pewną przydatność techniczną, ekonomiczną czy gospodarczą (know-how).

Trzeci aspekt zabezpieczania własności intelektualnej dotyczy zachowań i zabezpieczeń na poziomie pojedynczego człowieka i grup funkcjonujących $\mathrm{w}$ organizacji. Występują tu różne możliwe ścieżki zachowań uzależnione od czynników wewnętrznych (osoba) oraz czynników z otoczenia bliższego i dalszego. Powyższe cechy własności intelektualnej jako zasobu tworzą znaczące i pozytywne implikacje związane z zarządzaniem strategią innowacyjną (innowacyjności) przedsiębiorstwa ${ }^{1}$. W perspektywie wymogów zawartych $\mathrm{w}$ pracach dotyczących strategii innowacyjnej można sformułować pytanie o znaczenie tych cech dla praktyki formułowania i realizacji strategii innowacyjnej (Żebrowski, Waćkowski, 2011, s. 64). W tabeli 1 dokonano takiego odniesienia.

Podane w tabeli 1 odniesienia do cech zasobowych dla strategii innowacyjności mają uniwersalny charakter i są pochodną analizy literatury przedmiotu. Oznacza to, że owe cechy są listą nieskończoną, jak również nie jest możliwe przesądzanie o ich znaczeniu (hierarchii ważności). Niemniej jednak wyodrębnione przez autorkę pracy cechy składają się na „warunki brzegowe” kształtowania innowacyjności, wpisanej $\mathrm{w}$ działania przedsiębiorstw w wymiarze długofalowym (strategicznym). Dotyczy to zwłaszcza firm o dużym potencjale - najczęściej tych, których skala i zakres działania są znaczące. W przypadku małych firm, które w sposób uproszczony podchodzą do zarządzania procesem formułowania i realizacji strategii swoiste wyznaczniki wynikające $\mathrm{z}$ tych cech, będą trwałymi przesłankami i/lub czynnikami w działaniach koncentrujących się na zapewnieniu innowacyjności tych przedsiębiorstw. 
Tabela 1. Cechy własności intelektualnej a strategia innowacyjna (innowacyjności) organizacji

\begin{tabular}{|c|c|c|}
\hline $\begin{array}{l}\text { Typy cech w przekroju stopnia/ } \\
\text { stanu spełnienia atrybutu }\end{array}$ & Szczególny kontekst cechy & $\begin{array}{l}\text { Wpływ na kształtowanie strategii } \\
\text { innowacyjnej organizacji }\end{array}$ \\
\hline Stopień/stan zawłaszczalności & $\begin{array}{l}\text { Kontrola wytwarzania dobra i sposobu } \\
\text { wytwarzania }\end{array}$ & Oddziaływanie na formułowanie przesłanek strategii \\
\hline Stopień/stan podzielności & $\begin{array}{l}\text { Ograniczenia w formułowaniu podziału } \\
\text { wytworu }\end{array}$ & $\begin{array}{l}\text { Kreowanie zespołowości na etapie formułowania } \\
\text { i wdrożenia strategii }\end{array}$ \\
\hline Stopień/stan policzalności & $\begin{array}{l}\text { Źródło niepoliczalnych rezultatów twórczych } \\
\text { jednostek i zespołów }\end{array}$ & $\begin{array}{l}\text { Oddziaływanie na proces zarządzania strategią } \\
\text { innowacyjną (innowacyjności) }\end{array}$ \\
\hline Stopień/stan zużywalności & Płynność przekształcana w zasób materialny & $\begin{array}{l}\text { Wspieranie inspiracji i kreatywność jednostek } \\
\text { i zespołów oraz mechanizmy przyczynowo-skutkowe }\end{array}$ \\
\hline Stopień/stan komercjalizacji & $\begin{array}{l}\text { Dochodzenie do rozwiązań akceptowanych } \\
\text { przez rynek }\end{array}$ & $\begin{array}{l}\text { Wypełnianie treścią i wspieranie modeli biznesu } \\
\text { będących osią dla konkurowania poprzez własność } \\
\text { intelektualną }\end{array}$ \\
\hline Stopień/stan użyteczności & Zdolność do otwartego korzystania & $\begin{array}{l}\text { Otwieranie możliwości kształtowania modeli } \\
\text { biznesu w środowisku innowacyjnym organizacji }\end{array}$ \\
\hline Stopień/stan zabezpieczenia & $\begin{array}{l}\text { Zdolność do zabezpieczenia dostępu } \\
\text { i gwarancji właściwych zachowań } \\
\text { użytkowników i twórców }\end{array}$ & $\begin{array}{l}\text { Tworzenie przesłanek do działań w ramach } \\
\text { zarządzania strategią innowacyjną (w trzech } \\
\text { poziomach uwarunkowań }\end{array}$ \\
\hline
\end{tabular}

Źródło: opracowanie własne na podstawie: Żebrowski, Waćkowski, 2011

\section{Własność intelektualna jako prawno- -organizacyjna forma własności zasobów organizacji innowacyjnej}

W praktyce społeczno-gospodarczej instytucja własności prawnej odgrywa ważną rolę w procesie efektywnego rozwoju gospodarki każdego kraju. Jej znaczenie staje się kluczowe, gdy potrzebne jest opisywanie własności intelektualnej. Z ekonomicznego punktu widzenia wyjaśnienie istoty własności ujęto w tzw. property rights theory. Teoria ta o liberalnym podejściu odniosła się do struktury własności wynikającej ze stosunku podmiotu gospodarczego (jako właściciela zasobu) do przedmiotu własności, którym może on rozporządzać na zasadzie wyłączności w relacjach $\mathrm{z}$ innymi podmiotami gospodarczymi (De Alessi, 1980, s. 3). Tym samym gwarantuje się wyłączne prawo właściciela do rozporządzania zasobami i ich wykorzystywania, charakteryzujące się spersonalizowanym, wyłącznym prawem do użytkowania, kontroli oraz przekazywania zasobu i jednocześnie odpowiednie prawo ochrony przed naruszaniem własności przez inne podmioty gospodarcze (Cheung, 1970, s. 52). Tego rodzaju pełne prawo do rozporządzania dotyczy jednak tylko rzeczowo ograniczonego zakresu obowiązywania prawa własności. Tym samym prawo własności różni się zarówno w aspekcie metodycznym, jak i rzeczowym od pełnego prawa do określonego zasobu (Bielig, 2014, s. 17).

Własność pojmowana jako stosunek prawny między podmiotami gospodarczymi w wymiarze ekonomicznym wymaga dokładnego określenia trzech obszarów:

- osobistego przypisania do właściciela;

- stosunku do innych podmiotów gospodarczych;

- statusu własnościowo-prawnego w kontekście praw do ekonomicznego wykorzystania i związanych z nim praw do kontroli i zabezpieczania.
Status własnościowo-prawny ma kluczowe znaczenie. W praktyce określa on prawo do użytkowania zasobu, prawo do zatrzymania dochodów z jego użytkowania, prawo do wprowadzania zmian $\mathrm{w}$ jego formie i treści, prawo do dobrowolnego odstąpienia tych praw lub praw cząstkowych innemu podmiotowi gospodarczemu (prawo do transferu). Zatem struktury prawa własności kształtują siatkę stosunków multilateralnych pomiędzy różnymi podmiotami gospodarczymi zainteresowanymi użytkowaniem zasobów, nadając im indywidualne kompetencje w formie zestawu praw własności. H. Demsetz (1967, s. 347) wykazuje, że właściciel w ramach funkcji alokacyjnej własności optymalizuje ekonomicznie swoje procesy użytkowania. Stabilność struktur własnościowo-prawnych tworzy jednocześnie niezbędne warunki ramowe i bezpieczeństwo prawne. Analizy problemu wskazują na wcześniejsze pojawienie się instytucji własności niż instytucji prawa własności (Demsetz, 1967, s. 347-359).

W podobny sposób można objaśnić stosunek pojęcia własności do regulacji prawnych, instytucji politycznych i - oczywiście - państwa. Obserwacja zmian samej instytucji własności, pojawianie się nowych form własności, zwłaszcza zaś ekspozycja własności intelektualnej, stanowią podstawę dyskusji i oceny znaczenia rynkowego tej ostatniej. C. Strzeszewski (1981, s. 23-24) dokonuje wszechstronnej analizy kategorii własności, nawiązując do literatury z zakresu filozofii i nauk społecznych, $\mathrm{w}$ pełni uznając interdyscyplinarny charakter pojęcia własności. Tradycyjnie własność definiowano jako prawo czynienia z rzeczą wszystkiego, co nie jest prawnie zakazane przez dany system normatywny. Wśród rzeczy w rozumieniu prawa cywilnego już za czasów rzymskich zaczęto wyróżniać rzeczy niematerialne (tzw. res incorporales). Pomysł, aby własność odnosić do idei, a więc czegoś, czego nie można zobaczyć bezpośrednio, a co może 
się jedynie przejawiać $\mathrm{w}$ różnych zewnętrznych formach (pieczęciach, rysunkach, tekstach, projektach), jest późniejszy. Należy do tradycji nadawania przywilejów przez władzę państwową. Powszechność pojęcia „własność” rozumianego jako absolutne i w pewnym sensie naturalne prawo do rzeczy jest zakorzenione głęboko w kontekście pierwotnych znaczeń. Definicyjna zwartość czy wręcz prostota sprawiła, że pojęcie to zaczęto odnosić do wielu innych ekonomicznie istotnych wartości (Kaczmarczyk, 2017 , s. 65). W ten sposób bezpośrednio rozszerzono reżim własności na wytwory ludzkiego umysłu, na rezultaty inwencji twórczej i kreatywności człowieka (Dereń, 2014, s. 45-46). W konsekwencji rozciągnięto też jej postrzeganie na prawny wymiar tego rodzaju aktywności.

\section{Własność intelektualna w badaniach międzynarodowych i krajowych}

W sprawozdaniu z lat 2016/2017 dotyczącym MŚP w UE wykazano, że organizacje te zapewniają 57\% wartości dodanej w UE. Szacuje się jednak, że tylko około 30-60\% MŚP przetrwa dłużej niż 5 lat działalności (Annual report ..., 2017). Warunkiem umożliwiającym wydłużenie tego okresu, a więc przetrwanie i dalszy rozwój MŚP jest innowacyjność. Pozwala ona przedsiębiorstwom umacniać się i rozwijać, a także zatrudniać więcej osób, co w efekcie przekłada się na większą i silniejszą gospodarkę Unii Europejskiej (EUIPO, 2019b).

We wspólnym projekcie EUIPO i Europejskiego Urzędu Patentowego (EPO) „Przedsiębiorstwa wysokiego wzrostu i prawa własności intelektualnej” stwierdzono, że MŚP z zarejestrowanymi prawami własności intelektualnej mają o $21 \%$ więcej szans na doświadczenie wzrostu w późniejszym okresie i o $10 \%$ więcej szans, aby stać się przedsiębiorstwami wysokiego wzrostu. Ponadto te spośród MŚP, które korzystają z bogatych zasobów własności intelektualnej, mają jeszcze większe szanse na osiągnięcie wysokiego wzrostu gospodarczego (EUIPO, 2019a).

W 2016 r. EUIPO opublikowało pierwsze zestawienie wyników dla MŚP w zakresie własności intelektualnej, aby przedstawić pewien wgląd $\mathrm{w}$ to, dlaczego MŚP nie chronią formalnie własności intelektualnej i jakie napotykają problemy związane $\mathrm{z}$ tymi zasobami. Analogiczne badania przeprowadzono w 2019 roku (EUIPO, 2019b). Wykorzystując dane Eurostatu, EUIPO dobrało reprezentatywną próbę warstwową MŚP ze wszystkich 28 państw członkowskich UE. Próbę dobrano tak, by zawierała nadpróbę MŚP z prawami własności intelektualnej w porównaniu z populacją ogólną (średnio 50\% właścicieli zasobów intelektualnych), żeby można było zebrać odpowiednie wyniki dotyczące kwestii związanych z posiadaniem własności intelektualnej. Ogółem przeprowadzono 8349 wywiadów z MŚP, obejmujących wiele sektorów oraz wielkości przedsiębiorstw i krajów. Dla większości analiz w omawianym sprawozdaniu MŚP podzielono na dwie podgrupy: podmioty, które oświadczyły, że są właścicielami własności intelektualnej (4401) i podmioty, które oświadczyły, że nie są właścicielami takich zasobów (3948). Analogicznie do badania z 2016 roku dotyczącego wyników dla MŚP w zakresie praw własności intelektualnej wywiady z MŚP przeprowadzono telefonicznie z opcją ukończenia procesu online. Kwestionariusz był dostępny w 23 językach UE, a wywiady przeprowadzono w języku wybranym przez MŚP.

Jeśli chodzi o najważniejsze ustalenia, to większość MŚP (58\%) twierdzi, że jest innowacyjna. Istnieje większe prawdopodobieństwo, że właściciele własności intelektualnej będą bardziej innowacyjni, przy czym 73\% twierdzi, że tak jest, w porównaniu z 42\% podmiotów niebędących właścicielami takich zasobów. Większość innowacji dotyczy rozwoju nowych produktów, przy czym w tej dziedzinie innowacje wprowadza 63\% właścicieli praw własności intelektualnej i 31\% podmiotów niebędących właścicielami takich praw. Ponadto właściciele praw własności intelektualnej prawie dwukrotnie częściej niż podmioty niebędące właścicielami współpracują $\mathrm{z}$ innymi organizacjami nad nowymi innowacjami. Najczęstszymi partnerami właścicieli zasobów własności intelektualnej w zakresie współpracy są uniwersytety i środowiska akademickie, zaangażowane w prawie jednej trzeciej przypadków (32\%). Podmioty niebędące właścicielami własności intelektualnej wolą współpracować z dużymi przedsiębiorstwami (34\%) (EUIPO, 2019b).

Najczęściej wykorzystywanym źródłem informacji dla rozwoju biznesu w przypadku MŚP, będących właścicielami zasobów własności intelektualnej, jest Internet, przy czym 55\% podmiotów $\mathrm{z}$ tej grupy korzysta $\mathrm{z}$ tej metody. Na kolejnych miejscach znajdują się takie źródła jak izby handlowe (23\%) i radcy prawni (22\%).

Jeśli chodzi o stan wiedzy na temat własności intelektualnej, to większą znajomość tej problematyki mają właściciele tych praw: 77\% właścicieli zna je umiarkowanie lub bardzo dobrze w porównaniu z 52\% podmiotów niebędących właścicielami.

Jednym z kluczowych czynników intensywniejszego wykorzystania zasobów własności intelektualnej jest poprawa zrozumienia korzyści wynikających $\mathrm{z}$ tych praw. Główne powody rejestracji praw własności intelektualnej, jakie podawali właściciele tych praw należący do MŚP, to zapobieganie kopiowaniu (59\%), zwiększone bezpieczeństwo prawne $(58 \%)$ oraz poprawa wizerunku i wartości firmy (36\%). Gdy dokonano analizy według wielkości przedsiębiorstwa, kolejność dla MŚP pozostaje taka sama. Jednak mikroprzedsiębiorstwa kładą większy nacisk na znaczenie bezpieczeństwa prawnego niż na zapobieganie kopiowaniu.

W przypadku podmiotów niemających zarejestrowanych praw wyłącznych głównym powodem niedokonania rejestracji był brak wiedzy o tym, czym jest własność intelektualna i jakie wynikają z niej korzyści. Odsetek podający ten powód wzrósł z 25\% w 2016 r. do 38\% w 2019 r. W rzeczywistości $61 \%$ podmiotów niebędących właścicielami praw własności intelektualnej rozważyłoby rejestrację, gdyby lepiej rozumiało znaczenie tych zasobów. Drugi najbardziej popularny powód niedokonania rejestracji w 2019 r. jest bardziej altruistyczny - 21\% MŚP chciało, by ich innowacje były bezpłatnie dostępne dla wszystkich pragnących z nich korzystać (EUIPO, 2019b). 
Własność intelektualna jest często postrzegana przez MŚP raczej jako koszt niż inwestycja, ponieważ wartość dodana jest często nierozumiana. Jedynie $25 \%$ podmiotów średniej wielkości będących właścicielami zasobów intelektualnych dokonało profesjonalnej wyceny swoich aktywów niematerialnych, a wartość ta spada do $20 \%$ w przypadku małych i mikroprzedsiębiorstw będących właścicielami praw własności intelektualnej. Ogólny brak zrozumienia tego, jak zmaksymalizować potencjał własności intelektualnej, jest widoczny w wielu MŚP, które próbowały pozyskać środki finansowe na podstawie swoich aktywów niematerialnych. Choć dostęp do środków finansowych stanowi jeden z największych problemów dla MŚP, tylko $13 \%$ właścicieli praw wyłącznych spróbowało pozyskać środki finansowe, wykorzystując swoje aktywa niematerialne ( $9 \% \mathrm{z}$ nich się powiodło).

Jeśli chodzi o komercjalizację, to $24 \%$ ankietowanych właścicieli praw własności intelektualnej, z którymi przeprowadzono wywiady, podpisało umowę licencyjną obejmującą wybraną kategorię własności intelektualnej, przy czym $71 \%$ z podmiotów udzieliło licencji na swoją własność intelektualną innym organizacjom. Przesłankami aktywności licencyjnej była chęć uzyskania dodatkowych przychodów (27\%) i ekspansja na nowe obszary (sektory i obszary geograficzne) bez ponoszenia związanych z tym kosztów (23\%).

Omówione najnowsze badania przeprowadzone na zlecenie EUIPO ilustrują poziom i stan wiedzy na temat zasobów własności intelektualnej w europejskim sektorze MŚP. Przeprowadzone przez autorkę badania w 2015 roku objęły grupę 137 MŚP oraz dużych przedsiębiorstw. Podstawowym kryterium doboru podmiotów było prowadzenie przez nie innowacyjnej działalności gospodarczej oraz lokalizacja - województwo dolnośląskie. Zastosowana w badaniach ankieta zawierała „x” pytań merytorycznych i „z” porządkowych. Tytuł, który przyjęto jako swoistą preambułę badań, określono jako: Analiza zasobów własności intelektualnej jako determinanta potencjału innowacyjnego. Wśród badanych przedsiębiorstw 15\% stanowiły mikroprzedsiębiorstwa zatrudniające do 10 pracowników, 33\% przedsiębiorstwa małe zatrudniające do 50 pracowników oraz 31\% średnie (50-250 pracowników). W badanej grupie ponad $21 \%$ to przedsiębiorstwa duże, zatrudniające ponad 250 pracowników. Jak wykazano w ankiecie, blisko $40 \%$ badanych ograniczało swoją działalność do analizowanego regionu, 33\% działało na rynku krajowym, a 29\% na rynku międzynarodowym. Połowa badanych świadczy usługi, reszta prowadzi działalność w zakresie produkcji i handlu.

Badania, o których mowa wyżej, ponownie przeprowadzono na przełomie lat 2018/2019, w oparciu o te same kryteria co w roku 2015, jednak w mniejszej grupie respondentów, obejmującej 60 przedsiębiorstw. Wśród badanych przedsiębiorstw $10 \%$ stanowily mikroprzedsiębiorstwa zatrudniające do 10 pracowników, 33\% przedsiębiorstwa małe zatrudniające do 50 pracowników oraz $31 \%$ średnie (50-250 pracowników). Pozostałe $26 \%$ stanowiły duże przedsiębiorstwa zatrudniające ponad 250 pracowników.

$\mathrm{W}$ badaniach skoncentrowano się na poznaniu uwarunkowań związanych $\mathrm{z}$ realną oceną stanu, jak też postrzegania własności intelektualnej w kontekście czterech kluczowych obszarów badawczych. W tabeli 2 podano oszacowanie tego problemu badawczego. Przyjęto, że ocena każdego $\mathrm{z}$ badanych obszarów przybiera trzy poziomy: $\mathrm{W}$ - wysokie postrzeganie danego aspektu, $\mathrm{P}$ - przeciętne postrzeganie, $\mathrm{N}$ - niskie postrzeganie.

Dla poszczególnych stanów (obszarów) badawczych własności wprowadzono syntetyczne wskaźniki $\mathrm{W}^{1}, \mathrm{~W}^{2}$, $\mathrm{W}^{3}$. Wskaźniki te służą do syntetycznego, liczbowego wyrażenia rezultatów badań w trzech obszarach własności. Sposób ich wyznaczenia został podany poniżej.

Przedstawione oszacowania postrzegania własności intelektualnej w czterech wskazanych aspektach stanowią interesujący obraz kojarzenia tej specyficznej kategorii zasobów niematerialnych.

Tabela 2. Postrzeganie własności intelektualnej przez menedżerów w odniesieniu do czterech ogólnych aspektów własności

\begin{tabular}{|c|c|c|c|c|c|}
\hline $\begin{array}{l}\text { Ogólne aspekty } \\
\text { własności } \\
\text { intelektualnej }\end{array}$ & $\begin{array}{l}\text { Ogółem } \\
\left(N_{0}=137\right)\end{array}$ & $\begin{array}{c}\text { Mikro- } \\
\text { przedsiębiorstwa } \\
\left(\mathrm{N}_{\mathrm{mk}}=27\right)\end{array}$ & $\begin{array}{c}\text { Małe } \\
\text { przedsiębiorstwa } \\
\left(\mathrm{N}_{\mathrm{ma}}=50\right)\end{array}$ & $\begin{array}{c}\text { Średnie } \\
\text { przedsiębiorstwa } \\
\left(\mathrm{N}_{\mathrm{sr}}=\mathbf{3 1}\right)\end{array}$ & $\begin{array}{c}\text { Duże } \\
\text { przedsiębiorstwa } \\
\left(\mathrm{N}_{\mathrm{du}}=29\right)\end{array}$ \\
\hline $\begin{array}{l}\text { Przypisanie do } \\
\text { właściciela }\end{array}$ & $\begin{array}{l}\mathrm{W}=22 \\
\mathrm{P}=15 \\
\mathrm{~N}=80\end{array}$ & $\begin{array}{c}\mathrm{W}=2 \\
\mathrm{P}=0 \\
\mathrm{~N}=25 \\
{\left[\mathrm{~W}^{\mathbf{1}}=1,3\right]}\end{array}$ & $\begin{array}{c}\mathrm{W}=10 \\
\mathrm{P}=0 \\
\mathrm{~N}=30 \\
{\left[\mathrm{~W}^{1}=1,6\right]}\end{array}$ & $\begin{array}{c}\mathrm{W}=4 \\
\mathrm{P}=6 \\
\mathrm{~N}=21 \\
{\left[\mathrm{~W}^{1}=1,93\right]}\end{array}$ & $\begin{array}{c}\mathrm{W}=6 \\
\mathrm{P}=9 \\
\mathrm{~N}=14 \\
{\left[\mathrm{~W}^{1}=2,45\right]}\end{array}$ \\
\hline $\begin{array}{l}\text { Relacja do innych } \\
\text { podmiotów }\end{array}$ & $\begin{array}{l}\mathrm{W}=30 \\
\mathrm{P}=46 \\
\mathrm{~N}=61\end{array}$ & $\begin{array}{c}\mathrm{W}=10 \\
\mathrm{P}=10 \\
\mathrm{~N}=7 \\
{\left[\mathrm{~W}^{2}=3,22\right]}\end{array}$ & $\begin{array}{c}\mathrm{W}=10 \\
\mathrm{P}=10 \\
\mathrm{~N}=30 \\
{\left[\mathrm{~W}^{2}=2,2\right]}\end{array}$ & $\begin{array}{c}\mathrm{W}=4 \\
\mathrm{P}=11 \\
\mathrm{~N}=16 \\
{\left[\mathrm{~W}^{2}=2,23\right]}\end{array}$ & $\begin{array}{c}\mathrm{W}=6 \\
\mathrm{P}=15 \\
\mathrm{~N}=8 \\
{\left[\mathrm{~W}^{2}=2,86\right]}\end{array}$ \\
\hline $\begin{array}{l}\text { Zakres wykorzystania } \\
\text { i zabezpieczenia }\end{array}$ & $\begin{array}{l}\mathrm{W}=37 \\
\mathrm{P}=55 \\
\mathrm{~N}=45\end{array}$ & $\begin{array}{c}\mathrm{W}=5 \\
\mathrm{P}=7 \\
\mathrm{~N}=15 \\
{\left[\mathrm{~W}^{3}=2,26\right]}\end{array}$ & $\begin{array}{c}\mathrm{W}=10 \\
\mathrm{P}=30 \\
\mathrm{~N}=10 \\
{\left[\mathrm{~W}^{3}=3,0\right]}\end{array}$ & $\begin{array}{c}\mathrm{W}=13 \\
\mathrm{P}=11 \\
\mathrm{~N}=7 \\
{\left[\mathrm{~W}^{3}=3,07\right]}\end{array}$ & $\begin{array}{c}\mathrm{W}=17 \\
\mathrm{P}=9 \\
\mathrm{~N}=3 \\
{\left[\mathrm{~W}^{3}=3,97\right]}\end{array}$ \\
\hline
\end{tabular}

Źródło: opracowanie wtasne na podstawie uzyskanych wyników badań w 2015 i 2019 r. 
Najniżej wyceniony został obszar osobistego przypisania właściciela w kategorii mikroprzedsiębiorstw. Wynika to m.in. $\mathrm{z}$ niedostrzegania znaczenia powiązania takich zasobów z konkretnymi pracownikami i ewentualną próbą „zawłaszczania” tych zasobów na poziom organizacyjny, a nawet swój własny. W tym aspekcie menedżerowie i właściciele małych oraz średnich organizacji wykazują większą skłonność $\mathrm{w}$ identyfikowaniu własności intelektualnej z przypisywaniem ich z twórcami-pracownikami. Najwyższą wartość wskaźnik $\mathrm{W}^{1}$ przyjmuje dla dużych przedsiębiorstw $(2,45)$.

Drugi obszar postrzegania własności intelektualnej, który odnosił się do relacji gospodarczych, był na znacznie wyższym poziomie dla kategorii mikroprzedsiębiorstw. Wynika to bądź z samodzielnego wykorzystania obcych rozwiązań technologicznych, organizacyjnych w ramach posiadanych umów o korzystanie $\mathrm{z}$ zasobów intelektualnych, bądź podejmowania/planowania współpracy $\mathrm{z}$ dużymi partnerami biznesowymi. Wskaźnik $\mathrm{W}^{2}$ liczony według wskazanych zasad dla najmniejszych organizacji był wyższy niż dla kategorii małych przedsiębiorstw i wynosił 3,22 wobec 2,2 tych drugich, który z kolei był zbliżony do wartości wskaźnika dla średnich przedsiębiorstw $(2,23)$. Podobnie jak w pierwszym przypadku (obszarze) najwyższą wartość $\mathrm{W}^{2}$ przyjmuje wskaźnik dla dużych przedsiębiorstw $(2,86)$.

Trzeci obszar można było w badaniach oszacować w sposób najbardziej bezpośredni, ponieważ wiele pytań odnosiło się do komercjalizacji i zabezpieczeń własności $\mathrm{w}$ praktyce oraz $\mathrm{w}$ działaniach na przyszłość. Mimo że wskaźnik $\mathrm{W}^{3}$ dla mikroprzedsiębiorstw był wyższy niż np. w obszarze pierwszym, to nie może być uznany jako satysfakcjonujący ze względu na większość (15) przypadków ocenionych na poziomie niskim. Liczbowo wynosił on 2,26. Małe przedsiębiorstwa i średnie miały ten wskaźnik wyższy, odpowiednio: 3,0 i 3,07. Podobnie, jak w przypadku pierwszym i drugim, najwyższą wartość $\mathrm{W}^{3}$ przyjmuje wskaźnik dla przedsiębiorstw dużych $(3,97)$.

Ogólny wniosek w świetle tak sporządzonej analizy skłania do stwierdzenia, że aktualne funkcjonujące mikroprzedsiębiorstwa są raczej nastawione w przestrzeni własności intelektualnej na skorzystanie z okazji związanych $\mathrm{z}$ kooperacją $\mathrm{z}$ innymi podmiotami gospodarczy$\mathrm{mi}$, a nie na budowanie szans rynkowych na własnych innowacjach. Małe przedsiębiorstwa wykazują pewnego rodzaju "samozadowolenie” z uzyskanej pozycji, raczej koncentrują się, jeśli chodzi o własność intelektualną, na przetrwaniu i zachowaniu dotychczasowej formuły funkcjonowania. Menedżerowie i właściciele średnich przedsiębiorstw mają tylko nieznacznie wyższy porównywalny poziom oceny znaczenia własności intelektualnej dla funkcjonowania ich firm. Najlepiej w badaniu wypadły duże przedsiębiorstwa. Wynika to zapewne $\mathrm{z}$ tego, że przedsiębiorstwa te mają - w porównaniu z MŚP - świadomość, iż wykorzystanie własności intelektualnej i jej ochrona zwiększa wartość firmy i efektywność jej działania. Oczywiście nie jest to tylko kwestia świadomości, ale także posiadanej infrastruktury technicznej, organizacyjnej oraz wyspecjalizowanej kadry menedżerskiej, która posiada umiejętności niezbędne do zarządzania posiadanymi zasobami intelektualnymi.

Opisane wyniki badań to objaw swoistej dezorientacji. Jako społeczeństwo stale powołujemy się na wartości i reguły wypracowane w epoce industrialnej i XX-wiecznej rzeczywistości gospodarczej - podczas gdy dla przedsiębiorstw funkcjonujących w XXI wieku standardem rozwoju jest model innowacyjny polegajacy na dostarczaniu na rynek coraz bardziej atrakcyjnej oferty przy wykorzystaniu jakościowych czynników rozwoju. Rozwój przedsiębiorstw oparty jest na zasobach własności intelektualnej. To ona odgrywa istotną rolę w podejmowaniu decyzji gospodarczych. Nowe innowacyjne rozwiązania, wynalazki, wzory użytkowe, wzory przemysłowe, znaki towarowe, know-how itd. pojawiają się codziennie w przedsiębiorstwach i na rynku. Pomysły na nie kreowane są przez pracowników, klientów, a także często pod wpływem działań konkurencji. Dlatego tak ważny jest stan wiedzy na temat zasad zabezpieczania zasobów intelektualnych przed ich utratą, a tym samym utratą korzyści z ich posiadania.

Wydaje się, że powodów niskiej skłonności i potrzeby (szczególnie średnich przedsiębiorstw) do rozwijania własnej innowacji upatrywać należy w braku systemowego podejścia do podejmowanych działań na rzecz procesu oraz strategii innowacji. Dla tej wielkości organizacji konkretyzacja pojęcia strategii innowacyjnej jest wyłaniającą się szansą. Organizacja innowacyjna nastawiona na funkcjonowanie $\mathrm{z}$ wykrystalizowaną strategią innowacyjną interpretuje dla swoich potrzeb sygnały we wszystkich znanych wymiarach analizy otoczenia dalszego. Jej specyfika nadaje tym analizom odpowiedni kierunek, np. popyt rynkowy na innowacje, nawyki, obyczaje, wartości w społeczeństwie, technologie transformujące dobra intelektualne w materialne produkty i usługi.

\section{Podsumowanie}

0 mówione $\mathrm{w}$ niniejszym artykule badania EUIPO oraz badania własne wskazują, że poziom wiedzy i znaczenia sfery własności intelektualnej, tak kluczowej w budowaniu innowacyjności i czerpaniu korzyści z twórczej kreatywności zasobów ludzkich, jest nadal w sektorze przedsiębiorstw MŚP na niskim poziomie. Niedostateczna ochrona własności intelektualnej i niższa aktywność wynalazcza nie tylko utrudniają zdobywanie przewagi rynkowej i sukcesów komercyjnych przedsiębiorstwom, ale jednocześnie ograniczają powstawanie kolejnych nowych rozwiązań, decydujących o dalszym postępie naukowo-technicznym. Szczególnie ważne i ekonomicznie racjonalne jest zabezpieczenie i ochrona zasobów własności intelektualnej. Ochrona ta ułatwia przedsiębiorstwom czerpanie korzyści z ich zdolności innowacyjnej i twórczej, co pomaga i zachęca do utrzymywania wysokiego poziomu innowacyjności. Ochrona IP umożliwia bowiem gwarancję czasowej wyłączności na wysoką sprzedaż dzięki uzyskanemu prawnie monopolowi i stanowi zwykle zachętę do ponoszenia dalszych nakładów na rozwój innowacyjności. 
Standardem rozwoju współczesnych organizacji jest model innowacyjny polegający na dostarczaniu na rynek coraz bardziej atrakcyjnej oferty. Podstawą funkcjonowania tego modelu jest własność intelektualna. Niematerialny charakter i specyficzne cechy (atrybuty) własności intelektualnej (niezawłaszczalność, niepoliczalność, niepodzielność, zdolność do komercjalizacji, użyteczność, zdolność do zabezpieczania (ochrony) i strategiczność) są zorientowane właśnie na rozwój innowacji. Zasoby własności intelektualnej uznawane są za kluczowe i tworzą znaczącą wartość dodaną przedsiębiorstwa. Dlatego organizacje powinny podejmować różnorakie działania polegające na efektywnym wykorzystaniu wartości strategicznej posiadanych praw wyłącznych. Niezbędna jest do tego znajomość istoty własności intelektualnej, jej specyficznych cech oraz reguł i zasad zabezpieczania oraz ochrony własności intelektualnej.

\section{dr hab. Aldona Małgorzata Dereń, prof. uczelni Politechnika Wrocławska \\ Wydział Informatyki i Zarządzania \\ ORCID: 0000-0002-2377-4573 \\ e-mail: aldona.deren@pwr.edu.pl}

\section{Przypis}

1) Zamiennie można używać określenia zarządzanie strategia własności intelektualnej.

\section{Bibliografia}

[1] Aaker D.A. (1991), Managing Brand Equity - Capitalizing on the Value of a Brand Name, The Free Press, New York.

[2] Annual Report on European SMSs 2016/2017. Focus on Self-employment, November 2017, https://op.europa.eu/en/publication-detail/-/publication/0b7b64b6-ca80-11e7-8e69-01aa75ed71a1/language-en/format-PDF, data dostępu: 23.03.2020 r.

[3] Bainbridge D. (2009), Intellectual Property, Pearson Education Limited, Essex, Harlow.

[4] Battilan J., Cascianno T. (2015), Overcoming Resistance to Organizational Change: Strong Ties and Affective Cooptation, Management Science, Vol. 59, No. 4, pp. 819-836.

[5] Bielig A. (2014), Rola własności intelektualnej w gospodarce. Teoria i praktyka, Oficyna Wydawnicza Szkoły Głównej Handlowej w Warszawie, Warszawa.

[6] Blair R.D., Cotter T.F., (2005) Intellectual Property Economic and Legal Dimensions of Rights and Remedies, Cambridge University Press, Cambridge.

[7] Boldren M., Levine D. (2008), Against Intellectual Monopoly, Cambridge University Press, Cambridge.

[8] Bratnicki M., Strużyna J. (2001), Przedsiębiorczość i kapitat intelektualny, Wydawnictwo Akademii Ekonomicznej, Katowice.

[9] Cheung S.N.S. (1970), The Structure of Contract. The Theory of a Non-exclusive Resource, „Journal of Law and Economics", Vol. 13, No. 1, pp. 49-70.

[10] Clayton M., Christensen, M., McDonald P., Raynor M.E. (2016), What Is Disruptive Innovation, „Harvard Business Review", No. 93, pp. 44-53.
[11] De Alessi L. (1980), The Economics of Property Rights: A Review of the Evidence, "Research in Law and Economics”, Vol. 2, R. Zerbe (ed.), JAI Press, Greenwich, pp. 1-47.

[12] Demsetz H. (1967), Toward a Theory of Property Rights, „American Economic Review”, Vol. 57, No. 2, pp. 347-359.

[13] Dereń A.M. (2015), Stan wiedzy na temat zarządzania $i$ ochrony własności intelektualnej $w$ przedsiębiorstwach sektora MŚP $w$ regionie Dolnego Ślaska, Raport z badań, Raport serii PRE, [w:] Raporty Wydziału Informatyki i Zarządzania Politechniki Wrocławskiej, Ser. PRE, Wrocław, Nr 29, s. 1-40.

[14] Dereń A.M. (2014), Zarządzanie własnościa intelektualna $w$ transferze technologii, Wyd. Difin, Warszawa.

[15] Drucker P.F. (1992), Innowacja i przedsiębiorczość. Praktyka i zasady, PWE, Warszawa.

[16] EUIPO (2019a), Komunikat Prasowy, 25 września 2019, Urząd Unii Europejskiej ds. Własności Intelektualnej, https:// euipo.europa.eu/tunnel-web/secure/webdav/guest/document_library/observatory/documents/IPContributionStudy/ IPR-intensive_industries_and_economicin_EU/IP_Contribution_Report_092019_pr_pl.pdf, data dostępu: 23.03.2020 r.

[17] EUIPO (2019b), Zestawienie wyników dla MŚP w zakresie własności intelektualnej na rok 2019, Urząd Unii Europejskiej ds. Własności Intelektualnej, https://euipo.europa. eu/tunnelweb/secure/webdav/guest/document_library/ observatory/documents/IP_sme_scoreboard_study_2019/ executiveSummary/executive_summary_2019_pl.pdf, data dostępu: 23.03.2020 r.

[18] Grandstrand O. (1999), The Economics and Management of Intellectual Property. Towards Intellectual Capitalism, Edward Elgar, Cheltenham, Northampton.

[19] Kaczmarczyk M. (2013), Czy własność intelektualna jest własnościa, [w:] M. Danielowicz, A. Tarkowski (red.), Prawo autorskie $w$ czasach zmiany. O normach korzystania $z$ treści, Centrum Cyfrowe, Warszawa, s. 65-72.

[20] Konwencja o ustanowieniu Światowej Organizacji Własności Intelektualnej, sporządzona w Sztokholmie dnia 14 lipca 1967 r., Dz.U. 1975, Nr 9, poz. 4.

[21] Koźmiński A.K., Jemielniak D. (2008), Zarządzanie od podstaw, Wydawnictwa Akademickie i Profesjonalne, Warszawa.

[22] Krupski R., Piórkowska K. (2013), Użyteczność wiedzy $i$ innych zasobów niematerialnych dla innowacji i replikacji w badaniach empirycznych, Zeszyty Naukowe Uniwersytetu Ekonomicznego we Wrocławiu, Nr 298, s. 93-104.

[23] Palmen L. (2017), Nadchodzi druga transformacja, Rzeczpospolita z dnia 11.07.2017, http://www.rp.pl/Opinie/ 307109901-Luk-Palmen-Nadchodzi-druga-transformacja. html\#ap-3, data dostępu:19.07.2020 r.

[24] Pisano G.P. (2015), Potrzebujesz strategii innowacyjności, „Harvard Business Review Polska”, lipiec-sierpień, s. 95-103.

[25] Rajan Y.S. (2002), Empowering Indians. With Economic, Business and Technology Strengths for the Twenty First Century, Har Anand Publications, New Delhi.

[26] Strzeszewski C. (1981), Własność - zagadnienie społeczno-moralne, ODISS, Warszawa.

[27] Wiśniewska S. (2013), Skuteczność niekomercyjnych instytucji otoczenia biznesu we wspieraniu innowacji marketingowych małych $i$ średnich przedsiębiorstw, Wyd. Uniwersytetu Ekonomicznego, Kraków. 
[28] Zorska A. (2011), Koncepcja twórczej destrukcji J.A. Schumpetera $i$ jej odniesienie do przemian gospodarczych $w$ dobie obecnej rewolucji naukowo-technicznej, [w:] A. Zorska (red.), Chaos czy twórcza destrukcja? Ku nowym modelom $w$ gospodarce i polityce, Oficyna Wydawnicza SGH, Warszawa, s. 19-54.

[29] Żebrowski M., Waćkowski K. (2011), Strategiczne zarzqdzanie innowacjami. Strategie matych $i$ średnich przedsiębiorstw IT, Difin, Warszawa.

\section{Intellectual Property as a Key Resource of an Innovative Organisation}

\section{Summary}

The aim of the article is to indicate and analyse the specific features of intellectual property, which determine their orientation as a key strategic resource of the organ- isation in the context of development and competitiveness of enterprises in Poland. The basis for the analysis is the Report of the European Union Office for Intellectual Property (EUIPO), in which a summary of results for SMEs in the field of intellectual property of European companies was published. This report and own research carried out at the end of 2015 in a group of 138 companies from the Lower Silesia Province and the results of a repeated research carried out in 2019 on a smaller group of respondents, illustrate the key problems in the approach and perception of intellectual property as a key resource in the process of creating innovations in this group of companies.

\section{Keywords}

resources, intellectual property, enterprise, research 